\title{
EVALUATION OF EFFICACY OF INTRANASAL MIDAZOLAM SPRAY FOR PREANAESTHETIC MEDICATION IN PAEDIATRIC PATIENTS
}

Sneha P. Sikchi ${ }^{1}$, Sadhana Kulkarni², Mukund Parchandekar³, Purvashree Deshmukh².

1. Junior Resident-III, Department of Anaesthesiology, Government Medical College, Aurangabad.

2. Professor and Head, Department of Anaesthesiology, Government Medical College, Aurangabad.

3. Assistant Professor, Department of Anaesthesiology, Government Medical College, Aurangabad.

4. Junior Resident, Department of Anaesthesiology, Government Medical College, Aurangabad.

\section{CORRESPONDING AUTHOR:}

Dr Sneha P. Sikchi, C/O Mandhane hospital, Court road, Paithan-431107, Aurangabad (Maharashtra). Email-sneha_2011@yahoo.com

ABSTRACT: BACKGROUND: Preoperative anxiety and long-term behavioural problems are inevitable consequences in absence of preoperative sedation in paediatric patients undergoing surgery. An ideal premedicant removes fear and anxiety in tender minds of children and achieves a calm, sedated child for smooth induction of anaesthesia and rapid recovery in postoperative period. Midazolam is the most commonly used premedicant in children as it satisfies most of the criteria of ideal premedicant but its route of administration is a debatable issue in anaesthesia practice. AIMS: This study evaluated the efficacy of atomized intranasal midazolam spray as a painless, userfriendly, needleless system of drug administration for pre-anaesthetic medication in paediatric patients. SETTINGS AND DESIGN: Tertiary hospital, a prospective, randomized, controlled, clinical study. METHODS AND MATERIAL: 60 ASA physical status I children of 2-5 years age group, weighing 10-18 kg scheduled for routine surgeries participated in the study. Children were randomly assigned to Group M: Received intranasal midazolam spray in doses of $0.2 \mathrm{mg} / \mathrm{kg}$ and Group N: Received normal saline drops (1-2 drops/nostril). Patients were observed in preoperative room for $20 \mathrm{~min}$. Acceptance of drug, response to drug administration, sedation scale, separation score, acceptance to mask, recovery score and side effects of drug were noted. STATISTICAL ANALYSIS: Student ' $t$ ' test, standard error of difference between two means and Chi-square test. $p$ value $<0.05$ was considered as statistically significant. RESULTS AND CONCLUSION: $35 \%$ children in group $\mathrm{M}$ and $42.10 \%$ children in group $\mathrm{N}$ cried after drug administration who were not crying before drug administration ( $\mathrm{p}>0.05$ ). 20 min after premedication $76.66 \%$ in group $\mathrm{M}$ and $10.00 \%$ group $\mathrm{N}$, children showed satisfactory sedation $(\mathrm{p}<0.05) .73 .33 \%$ in group $\mathrm{M}$ while $26.66 \%$ in group $\mathrm{N}$, children showed acceptable parental separation and $86.66 \%$ in group $\mathrm{M}$ while $23.33 \%$ group $\mathrm{N}$, children showed satisfactory acceptance to mask $(\mathrm{p}<0.05)$. Transient nasal irritation in the form of rubbing of nose, watering, sneezing and lacrimation was observed in $40 \%$ children of group M.

Intranasal midazolam by atomized spray is safe and effective premedicant in paediatric patients. It produces effective sedation and anxiolysis in children. Transient nasal irritation is an undesirable side effect observed with intranasal route. 
KEY WORDS: atomized intranasal midazolam spray, pre-anaesthetic medication, children

Hospitalization, surgical operations and anaesthesia induction can be acutely traumatic to a child and may lead to lasting emotional and behavioural problems [1,2]. Considering the psychology of separation, they are at risk of developing parental separation syndrome which is a psychological trauma, accompanied with crying, yelling, struggling, and nightmares [3]. Preoperative anxiety occurring in upto $60 \%$ young children of 2-5 years of age is associated with unstable intraoperative vitals and a more painful recovery [4,5,6]. Both behavioral interventions (e.g. parental presence) and pharmacological interventions (e.g. sedative premedicants) are used to treat anxiety before surgery. Attending anaesthesiologists are better than mother in predicting the anxiety of children during induction of anesthesia [7,8].

Pharmacological intervention before surgery was found to be more effective intervention than either parental presence or no premedication-no parent present for managing a child's and parent's anxiety during the preoperative period [9]. Benzodiazepines, particularly Midazolam comes nearest to the ideal anxiolytic with minimal side effects [10,11]. Midazolam has been used for preoperative sedation by intramuscular [12], intravenous [13], rectal [14], oral [15,16], sublingual [17,18], and intranasal $[19,20]$ routes. But each route has its own advantages and disadvantages.

Intranasal midazolam administration, a convenient way to premedicate children has got rapid and reliable onset of action [21]. Midazolam in the form of drops, spray and nebulization is tried by nasal route $[22,23,24]$. Delivery by drops results in poor retention and drainage into the postnasal space [22]. A higher dose may need to be administered for adequate pre-anaesthetic medication when midazolam is given by nebulizer [24].

There are very few studies which used concentrated, atomized nasal spray, a good technique and slow and careful spraying of drug which solved the problem of volume and effective dose availability $[20,25,26]$. So the present study was carried out to evaluate the efficacy of intranasal midazolam by using atomizer spray for pre-anaesthetic medication in paediatric patients undergoing surgical procedures.

MATERIALS AND METHODS: After obtaining Institutional Ethical Committee approval, a pilot study was conducted on 10 children from each group (Group M- receiving intranasal midazolam by atomizer spray and Group $\mathrm{N}$ - receiving intranasal normal saline drops) to determine the sample size. A sample size of 4 was adequate to allow $80 \%$ power to detect a difference of $15 \%$ between the two groups, outcome parameter considered was sedation score [27]. We selected a larger group of 30 children in each group.

60 ASA grade I paediatric patients of age group 2-5 years, weighing 10-18 kg, scheduled for elective surgical procedures requiring general anaesthesia with expected duration not exceeding 75 min were included in the study. Elective surgeries lasting upto 75 min were selected as terminal half-life of intranasal midazolam is about $79 \pm 30$ mins [25]. Patients having nasal infection or nasal pathology, those allergic to midazolam, those taking any other sedative drug, those having any facial malformation, airway difficulty or history of snoring, any systemic illness and parents not willing to allow their child to participate in the study were excluded from the study. These children were divided into two groups of 30 each by systematic randomization, every even number patient received intranasal Midazolam spray and every odd number patient received Normal saline. 
Thorough pre-anaesthetic evaluation and investigations were carried out to find out any associated systemic illness. All children were fasted 4-6 hours before surgery. None of the children received any medication before arrival in the operating room. Child was then taken in preoperative room along with one of the parents for administration of intranasal midazolam spray or normal saline. Written informed consent in parent's language regarding voluntary participation of their child in the clinical drug trial was obtained.

On arrival in the preoperative room baseline pulse rate, respiratory rate, blood pressure and arterial oxygen saturation were recorded. Children were randomly allocated in one of the two groups.

Group M patients received intranasal midazolam spray $0.2 \mathrm{mg} / \mathrm{kg}$ [20] (each spray delivered $0.1 \mathrm{ml}$ or $0.5 \mathrm{mg}$ of drug, preparation containing midazolam $5 \mathrm{mg} / \mathrm{ml}$ with a maximum dose of 10 mg). Half of the dose was administered in each nostril. The child was placed on the parent's lap while their arms were gently restrained by one parental hand and the other hand used to tilt the forehead back $15^{\circ}$. Child was put in a comfortable position either lying down or sitting, after drug administration. Group N patients received normal saline nasal drops in both the nostrils, 1-2 drops/nostril.

Acceptance of drug was observed by using 3 point criteria as poor (score 1- Refused to accept medication), moderate (score 2- Accepted medication with difficulty), or good (score 3Accepted medication without complaint) [28]. Response to drug administration was noted as whether the child was crying previously or whether the child started crying after administration of drug. Children crying before administration of drug were excluded for observation of response to drug administration.

After administration of drug pulse rate, respiratory rate, blood pressure, $\mathrm{Spo}_{2}$, and state of sedation were recorded at $5 \mathrm{~min}$ interval for $20 \mathrm{~min}$. According to various studies time required for peak effect of intranasal midazolam is $20 \mathrm{~min}$ [18, 25]. Sedation score 1(Agitated) and 2 (Alert) were considered as unsatisfactory, while sedation score 3 (Calm), 4 (Drowsy), and 5 (Asleep) were considered as satisfactory [29]. Complications like nasal irritation, coughing, sneezing, lacrimation, hypoxia, laryngospasm, bradycardia, nausea, vomiting if any, were noted and treated by administering oxygen by face mask if arterial saturation dropped below $90 \%$ and Inj. Atropine for heart rate $<60 / \mathrm{min}$ as needed.

After 20 min of drug administration child was separated from the parents [18, 25]. Ease of separation from the parent was noted as excellent (Score 1- Patient unafraid, co-operative), good (Score 2-Slight fear or crying, quiet with assurance), fair (Score 3- Moderate fear, crying not quiet with assurance) and poor (Score 4- Crying, need for restraint) [30]. Separation score 1 and 2 were considered as satisfactory or acceptable and score of 3 and 4 were considered as unsatisfactory or said to have a difficult separation.

Vital parameters- pulse rate, blood pressure and $\mathrm{Spo}_{2}$ were monitored. Inhalational induction was done with 50:50 nitrous oxide/oxygen and sevoflurane 6-8\% by using face mask. Acceptance to mask (Reaction to gas induction) was noted by using 3 point criteria. Score 1 (excellent) and 2 (good) were considered as satisfactory and score 3 (poor) was considered as unsatisfactory acceptance of mask.

I.V. line was set up after induction and inj. Glycopyrrolate $4 \mu \mathrm{g} / \mathrm{kg}$ and Inj. Fentanyl $1 \mu \mathrm{g} / \mathrm{kg}$ i.v. were administered. Intubation was done with endotracheal tube of appropriate size under the 
effect of inj. Scoline $2 \mathrm{mg} / \mathrm{kg}$ i.v. Anaesthesia was maintained with Sevoflurane 1.5-2\% in 50:50 nitrous oxide / oxygen through Jackson Rees circuit and inj. Atracurium $0.5 \mathrm{mg} / \mathrm{kg}$ i.v. with its subsequent top-up doses as required. At the end of surgical procedure, patient was reversed with inj. Neostigmine $40 \mu \mathrm{g} / \mathrm{kg}$ and inj. Glycopyrrolate $8 \mu \mathrm{g} / \mathrm{kg}$ i.v. Extubation was performed when child was fully conscious, with stable vital parameters and could flex his thighs on the abdomen. Duration of anaesthesia was calculated from mask induction till extubation.

Children were observed in post anaesthesia care unit (PACU). Recovery assessment was done at $10 \mathrm{~min}$ interval for $30 \mathrm{~min}$ from the time of extubation by using a 10 point recovery room score. Multipara monitored $\mathrm{Spo}_{2}$, respiratory rate and blood pressure whereas activity, patients color and level of consciousness was assessed clinically each on a scale of $0-2$, to give a maximum total of 10 [29]. Satisfactory recovery i.e. recovery score of 8 or more and time taken for it were noted. Children were observed in PACU for 2 hrs and were then shifted to the ward when recovery score was $\geq 8$. They were followed up for 24 hours post-operatively to observe nasal irritation, ulceration, etc.

Data were recorded in proforma and analysed statistically by using student ' $\mathrm{t}$ ' test, standard error of difference between two means and Chi-square test. The SPSS version model was used. $\mathrm{p}<0.05$ was considered as statistically significant and $\mathrm{p}<0.01$ was considered as highly significant.

RESULTS: Children of both the sexes were included in the study. Mean age for group A was $3.28 \pm 1.05$ years and for group B was $3.43 \pm 1.023$ years (Table 1). Mean weight for group M was $12.46 \pm 1.99 \mathrm{~kg}$ and group $\mathrm{N}$ was $13.26 \pm 2.34 \mathrm{~kg}$. Duration of anaesthesia ranged from $30-75 \mathrm{~min}$ (mean $57 \pm 14.05$ ) for group $\mathrm{M}$ and $25-75$ min (mean $51.66 \pm 13.66$ ) for group $\mathrm{N}$. Both the groups were comparable as far as age, sex, weight and duration of anaesthesia is concerned ( $p>0.05)$.

There were no significant differences in pre-sedation vital parameters (Table 2) and baseline sedation score ( $p>0.05)$. Baseline sedation score ranged from 1-2 in all children of both the groups.

15/30 children from Group M and 11/30 children from Group N showed good acceptance to drug (Figure 1). 10 children from group $\mathrm{M}$ and 11 children from group $\mathrm{N}$ were crying before drug administration, so response to drug administration was difficult to assess and were excluded for this observation. Response to drug administration was evaluated as whether non-crying child had cried or not after drug administration. 07 from group $\mathrm{M}$ and 08 from group $\mathrm{N}$ non-crying children, cried after drug administration (Figure 1). No statistically significant difference was found between Group M and Group N (p>0.05).

$7 / 30(23.33 \%)$ children from group $\mathrm{M}$ and $27 / 30$ (90.00\%) children from group $\mathrm{N}$ had sedation score of 2 or less at $20 \mathrm{~min}$ and was considered as unacceptable sedation. 19/30 (63.33\%) children from group $\mathrm{M}$ and $3 / 30$ (10.00\%) children from group $\mathrm{N}$ had sedation score of 3 at 20 min. $4 / 30(13.33 \%)$ children from group $\mathrm{M}$ and $0 / 30(0 \%)$ children from group $\mathrm{N}$ had sedation score of 4 at $20 \mathrm{~min}$. Statistically significant difference was noted between both the groups at 10, 15 and 20 $\min (\mathrm{p}<0.05)$. (Table 3, Figure 2)

Complications like hypoxia, bradycardia, laryngospasm, nausea and vomiting were not observed in both the groups. Incidence of nasal irritation was found to be $12 / 30(40 \%)$ in group M and $4 / 30(13.33 \%)$ in group $\mathrm{N}$.

Post sedation vital parameters were noted over $20 \mathrm{~min}$ in both the groups (Table 4). A statistically significant difference was observed in respiratory rate, systolic blood pressure, 
diastolic blood pressure and oxygen saturation at and after $10 \mathrm{~min}$, and in pulse rate at and after 15 min, between the two groups $(\mathrm{p}<0.05)$.

$22 / 30(73.33 \%)$ children from group $\mathrm{M}$ and $08 / 30$ (26.66\%) children from group $\mathrm{N}$ showed satisfactory separation (score 1, 2). 8/30 (26.66\%) children from group $M$ and 22/30 (73.33\%) children from group $\mathrm{N}$ showed difficult separation (score 3, 4) (Table 5, Figure 2). 26/30 (86.66\%) children from group $\mathrm{M}$ and $7 / 30$ (23.33\%) children from group $\mathrm{N}$ showed satisfactory acceptance to mask (Table 6, Figure 2).

Intraoperative pulse rate, systolic blood pressure, diastolic blood pressure and oxygen saturation was stable and comparable (Table 7). Recovery score at $10 \mathrm{~min}, 20 \mathrm{~min}$, and $30 \mathrm{~min}$ was comparable in group $\mathrm{M}$ and group $\mathrm{N}(\mathrm{p}>0.05)$ (Table 8). Local effects like ulceration, mucosal redness were not observed in any of the patients.

DISCUSSION: Illness, hospitalization and especially surgical operations have significant emotional and psychological impact on the growing child and parents and those involved in the care of sick children have become increasingly aware of it [1]. The preschool children are least likely to cooperate with induction of anaesthesia and the most at risk to experience a negative psychological aftermath. We selected children in the age group of 2-5 years (Table 1) because children in this age group are at highest risk of separation anxiety due to their limited understanding $[4,19]$.

Infants and children are without significant apprehension or fear and that they can be quickly anaesthetized with an inhalation agent without prior sedation (or needle prick) is a fallacious and unreasonable concept [3]. The large quantity of literature published relating to premedication for children, is indicative that the search for the "ideal" agent has not yet yielded a universally satisfactory drug.

Across the world, midazolam is the most commonly used premedicant in paediatric patients [11]. Midazolam as a premedicant is administered to paediatric patients by various routes like intravenous, intramuscular, per rectal, sublingual, per oral, intranasal etc [13-15, 22,24]. The fact that no single route has achieved universal acceptance suggests that each route has its own merits and demerits. Intravenous and intramuscular routes have disadvantage of painful injections which children dislike. Discomfort to child, unpredictable absorption, longer time to achieve desired effect and concerns about modesty are problems related with per rectal route. Compliance with instructions to hold the sublingual medication for defined duration in infants and preschool children is not guaranteed. Bitter taste, low systemic availability and delayed peak effect put limitation on oral route of midazolam [19,31,32].

Owing to high mucosal vascularity, intranasal route offers rapid and virtually complete absorption of the drug [19]. Midazolam by nasal route can be administered in the form of drops, spray or nebulization. Concentrated, atomized midazolam nasal spray, delivers the drug in puffs which contain very minute particles which spread over a large surface area. Atomised nasal spray ensures accurate drug dosage $(0.5 \mathrm{mg} / 0.1 \mathrm{ml})$, increasing the concentration of midazolam reduces the volume of drug to be delivered, drug is applied over wide area with close mucosal contact. The bioavailability of intranasal midazolam by using a concentrated nasal spray may reach up to $83 \%$ [25]. Intranasal atomized midazolam has been tried in the doses of $0.2,0.3$, and $0.4 \mathrm{mg} / \mathrm{kg}$ [20,23], but no additional was found from the higher dosage and recommended using the lower dose of midazolam $0.2 \mathrm{mg} / \mathrm{kg}[29]$. 
In our study, acceptance of drug in group $\mathrm{M}$ was (50\%) and group $\mathrm{N}$ was $(36.67 \%)$. Response to drug administration was, 7 out of remaining 20 non crying children from group M, and 8 out of remaining 19 non crying children from group N, cried after drug administration. Difference in two groups was statistically insignificant. Though none of the child complained pain in our study, nasal discomfort might be there. Some children were temporarily distressed by the instillation of either midazolam or normal saline but rapidly settled down [29]. Intranasal midazolam by drops or spray produces unpleasant nasal irritation, the fine aerosol of spray would allow greater contact, seems to cause more nasal stinging than drops ${ }^{[22] .}$

To assess sedation status a 3- point, 4- point or 5- point sedation scale was used by previous investigators $[30,33,34]$. We used a 5-point sedation scale to assess the degree of sedation. In our study, 23/30 (76.66\%) children from group $\mathrm{M}$ and 3/30 (10.00\%) children from group $\mathrm{N}$ had acceptable sedation (i.e. score 3 or more) at 20 min (Table 3, Figure 2). 4/30 (13.33\%) children from group $M$ and none from group $\mathrm{N}$ had sedation score of 4 at $20 \mathrm{~min}$. None of children lost consciousness in either of the group. As far as level of sedation is concerned statistically significant difference was noted in both the groups at 10,15 and $20 \mathrm{~min}(\mathrm{p}<0.05)$. From these observations, it appears that onset of sedation after intranasal midazolam is about $10 \mathrm{~min}$ [19]. Rapid uptake and high bioavailability of intranasal midazolam resulting into high plasma concentration at $14 \pm 5 \mathrm{~min}$ is useful for rapid onset by intranasal midazolam spray [25].

In our study only nasal irritation / transient distress was observed and its incidence in group $\mathrm{M}$ was $12 / 30$ (40\%) and 4/30 (13.33\%) in group $\mathrm{N}$ which was statistically significant. Incidence of nasal irritation and crying was $56 \%$ and $71 \%$ in other studies [17,36]. Lugo R.A et al [37] recommended spraying of $4 \%$ lidocaine spray prior to midazolam spray for reducing irritation without affecting efficacy of midazolam. Dallman J A et al [38] (2001) suggested use of midazolam solution in cyclodextrin, which results in greater concentration of the drug as well as less $\mathrm{pH}$.

Anxiolysis was observed at parental separation and mask application by two different anxiolysis scales. In our study 22 (73.33\%) children from group M and 8 (26.66\%) children from group $\mathrm{N}$ showed satisfactory separation which was statistically significant $(\mathrm{p}<0.05)$. Parental separation was poor in group B (Table 5, Figure 2). Similar results were noted in other studies [19,35]. In our study 26 (86.66\%) children from group M and 7 (23.33\%) children from group N showed satisfactory acceptance to mask which was statistically significant $(\mathrm{p}<0.05)$ (Table 6, Figure 2). Comparable satisfactory mask application of $60 \%, 80 \%$ and $75 \%$ were observed in other studies [18,19,35].

In our study, intraoperative vitals (Table 7) and duration of anaesthesia were comparable in both the groups $(p>0.05)$. While studying on intranasal midazolam Zedie et al observed that vital signs remained stable with medication during the study period [39].

In our study, recovery score for group $\mathrm{M}$ vs group $\mathrm{N}$ at $10 \mathrm{~min}, 20 \mathrm{~min}$, and $30 \mathrm{~min}$ was comparable in both the groups ( $p>0.05$ ) (Table 8).Our results were comparable with other studies [19,29]. They stated that, in oral route a significant amount of drug undergoes first pass metabolism, in contrast this is not seen with intranasal midazolam, so recovery is not delayed.

However, there are some limitations of our study.

- The study could not be blinded, as the parents used to tell the evaluator anaesthesiologist about administration of spray or drops even without asking them. 
- Crying of the child after administration of the drug could be due to anxiety or nasal irritation that could not be differentiated.

As results with $0.2 \mathrm{mg} / \mathrm{kg}$ and $0.3 \mathrm{mg} / \mathrm{kg}$ intranasal midazolam spray are controversial, further study can be carried out comparing $0.2 \mathrm{mg} / \mathrm{kg}$ with $0.3 \mathrm{mg} / \mathrm{kg}$ for intranasal route [23,29]. Measures to reduce irritation like use of $4 \%$ lidocaine spray [37] before midazolam spray and midazolam solution in cyclodextrin ${ }^{[38]}$ can be tried.

Thus, we conclude from the present study that intranasal midazolam atomiser spray is an effective sedative and anxiolytic pre-anaesthetic medication in children. Transient nasal irritation was the only side effect observed. So, Intranasal midazolam was not only effective premedicant but also safe for paediatric patients.

\section{REFERENCES:}

1. Korsch Barbara M. The child and the operating room. Anesthesiology 1975; 43(2): 251-57

2. Lyons Barry, Cregg Nuala, Conway F, Casey W, Doherty P. Premedication for ambulatory surgery in preschool children: a comparison of oral midazolam and rectal thiopentone. Can J Anaesth 1995; 42(6):473-78

3. Vincent J Collins. Anesthesia for infants and children in Principles of Anesthesiology, General and Regional Anesthesia, Vincent J Collins, Lea and Febiger, Philadelphia, 3 ${ }^{\text {rd }}$ edition, Vol. 1, 1993, page 299- 302

4. Kain ZN, Mayes Linda C, O'Conner Theresa Z, Cicchetti DV. Preoperative anxiety in children: predictors and outcomes. Arch Pediatr Adolesc Med 1996; 150(12):1238-1245

5. Kain ZN, Shu Ming Wang, Mayes Linda C, Caramico LA, Hofstadter MB. Distress during induction of anaesthesia and postoperative behavioral outcomes. Anesth Analg 1999; 88:1042-47

6. Kain ZN, Mayes Linda C, Caldwell-Andrews AA, Karas DE, McClain BC. Preoperative anxiety, postoperative pain, and behavioral recovery in young children undergoing surgery. Pediatrics 2006; 118(2):651-58

7. McCann ME and Kain ZN. The management of preoperative anxiety in children: an update. Anesth Analg 2001; 93:98-105

8. MacLaren JE, Caitlin Thompson, Weinberg M, Fortier MA, Morrison DE, Danielle Perret. Prediction of preoperative anxiety in children: who is more accurate? Anesth Analg 2009; 108:1777-82

9. Kain ZN, Mayes Linda C, Shu-Ming Wang, Caramico LA, Hofstadter MB. Parental presence during induction of anaesthesia versus sedative premedication: which intervention is more effective? Anesthesiology 1998; 89(5):1147-56

10. Madej Tamara H. and Paasuke Rein T. Review article- anaesthetic premedication: aims, assessment and methods. Can J Anaesth 1987; 34(3):259-73

11. Kain ZN, Caldwell-Andrews, Krivutza DM, Weinberg ME, Shu-Ming Wang, Dorothy Gaal. Trends in the practice of parental presence during induction of anesthesia and the use of preoperative sedative premedication in the United States, 1995-2002: results of a follow-up national survey. Anesth Analg 2004; 98:1252-59 
12. Lam Christy, Udin RD, Malamed SF, Good DL, Forrest JI. Midazolam premedication in children: A pilot study comparing intramuscular and intranasal administration. Anesth Prog 2005; 52:56-61

13. Kaufman E, Davidson E, Sheinkman Z, Magora F. Comparison between intranasal and intravenous midazolam sedation (with or without patient control) in a dental phobia clinic. Oral Maxiollofac Surg 1994; 52(8):840-44

14. Lejus C, Testa S, Vigier T, Souron R. Midazolam for premedication in children: nasal vs. rectal administration. Eur J Anaesth 1997; 14:44-49

15. Sajedi P, Attari MA, Ghorbani A. Comparing effectiveness of oral and intranasal midazolam for premeditation in children. Journal of Research in Medical Sciences 2000; 5(1)

16. Lee-Kim Su Jun, Fadavi S, Punwani I, Koerber Anne. Nasal versus oral midazolam sedation for pediatric dental patients. Journal of Dentistry for Children 2004; 71(2):126-30

17. Karl HW, Rosenberger JL, Larach MG, Ruffle JM. Transmucosal administration of midazolam for pediatric patients: comparison of the nasal and sublingual routes. Anesthesiology 1993; 78(5):885-91

18. Kogan A, Katz J Efrat R, Eidelman LA. Premedication with midazolam in young children: a comparison of administration. Paediatr Anaesth 2002; 12(8):685-89

19. Bhakta P, Ghosh BR, Roy M, Mukherjee G. Evaluation of intranasal midazolam for preanaesthetic sedation in paediatric patients. Indian J Anaesth 2007; 51(2):111-116

20. Lane RD, Schunk JE. Atomized intranasal midazolam use for minor procedures in the pediatric emergency department. Pediatric Emergency Care 2008; 24(5):300-03

21. Malinovsky JM, Populaire C, Cozian A, Lepage JY, Lejus C, Pinaud M. Premedication with midazolam in children: Effects of intranasal, rectal and oral routes on plasma midazolam concentrations. Anaesthesia 1995; 50:351-54

22. Griffith N, Howell S, Mason DG. Intranasal midazolam for premedication of children undergoing day-case anaesthesia: comparison of two delivery systems with assessment of intra-observer variability. Br J Anaesth 1998; 81:865-69

23. Baldwa NM, Padvi AV, Dave NM, Garasia MB. Intranasal midazolam as premedication in paediatric patients. J Anesth, Jun 2012; 26(3): 346-50

24. McCormick ASM, Thomas VL, Berry D, Thomas PW. Plasma concentrations and sedation scores after nebulized and intranasal midazolam in healthy volunteers. Br J Anaesth 2008; 100(5):631-36

25. Knoester PD, Jonker DM, RTM van der Hoven, Vermeij TAC, Edelbroek PM, Brekelmans GJ, GJ de Haan. Pharmacokinetics and pharmacodynamics of midazolam administered as a concentrated intranasal spray. A study in healthy volunteers. Clin Pharmacol 2002; 53:50107

26. Bjorkman S, Rigemar G, Idvall J. Pharmacokinetics of midazolam given as an intranasal spray to adult surgical patients. Br J Anaesth 1997; 79:575-80

27. Dawson B, Trapp RG. In Basic and Clinical Biostatistics, $3^{\text {rd }}$ edition, Lange Medical Books/ McGraw-Hill Medical Publishing Division, New York, page - 180

28. Parnis SJ, Foate JA, Vander Walt JH, Short T, Crowe CE. Oral midazolam is an effective premedication for children having day-stay anaesthesia. Anesth Intensive Care 1992; 20:9-14 
29. Niall C.T.Wilton, John Leigh, Rosen DR, Pandit Uma A. Preanesthetic sedation of preschool children using intranasal midazolam. Anesthesiology 1988; 69(6):972-75

30. McMillan CO, Spahr-Schopfer IA, Sikich N, Hartley E, Lerman J. Premedication of children with oral midazolam. Can J Anaesth 1992; 39(6):545-50

31. Reves JG, Fragen RJ, Vinik HR, Greenblatt DJ. Midazolam: pharmacology and uses. Anesthesiology 1985; 62:310-24

32. Cote CJ. Preoperative preparation and premedication. Br J Anaesth 1999; 83(1): 16-28

33. Feld LH, Negus JB, White PF. Oral midazolam preanaesthetic medication in pediatric outpatients. Anesthesiology 1990; 73(5):831-34

34. Levine MF, Sphar-Schopfer IA, Elizabeth Hartley, Bruce MacPherson. Oral premedication in children: the minimum time interval for separation from parents. Can J Anaesth 1993; 40(8):726-29

35. Davis PJ, Tome JA, McGowan FX Jr, Cohen IT, Latta K, Felder H. Preanesthetic medication with intranasal midazolam for brief pediatric surgical procedures, Effect on recovery and hospital times. Anesthesiology 1995; 82(1):2-5

36. Narendra Kumar, Rohit Sharma, Mamta Sharma, Indu Verma, Meenaxi Sharma. Midazolam pre-medication in paediatrics: Comparison of the intranasal and sublingual routes by using an atomizer spray. Journal of Clinical and Diagnostic Research, Feb 2012; 6(1): 65-68

37. Lugo RA, Mark Fishbein, Nahata MC, Barbara Lininger. Complications of intranasal midazolam. Pediatrics 1993; 92(4):638

38. Dallman JA, Ignelzi MA Jr, Briskie DM. Comparing the safety efficacy and recovery of intranasal midazolam vs oral chloral hydrate and promethazine. Pediatr Dent 2001; 23(5) :424-30

39. Zedie N, Amory DW, Wagner BKJ, O’Hara DA. Comparison of intranasal midazolam and sufentanil premedication in pediatric outpatients. Clin Pharmacol Ther 1996; 59:341-48

TABLE 1: Showing age and sex distribution

\begin{tabular}{|l|l|c|l|l|l|l|}
\hline \multirow{2}{*}{$\begin{array}{l}\text { Age } \\
\text { Years }\end{array}$} & \multicolumn{4}{l}{ Number of children } & \multicolumn{4}{l|}{} \\
\cline { 2 - 7 } & Group $\mathrm{M}^{\times}$ & \multicolumn{4}{l|}{ Group N } & \multicolumn{2}{l|}{ Total } \\
\cline { 2 - 7 } & $\mathrm{M}$ & $\mathrm{F}$ & $\mathrm{M}$ & $\mathrm{F}$ & $\mathrm{M}$ & $\mathrm{F}$ \\
& No. of pts & No. of pts. & No. of pts & No. of pts & No. of pts & No. of pts \\
\hline $2-3.5$ & $15 / 30$ & $03 / 30$ & $10 / 30$ & $07 / 30$ & $25 / 30$ & $10 / 30$ \\
$3.6-5$ & $8 / 30$ & $04 / 30$ & $10 / 30$ & $03 / 30$ & $18 / 30$ & $07 / 30$ \\
\hline Total & $23 / 30$ & $07 / 60$ & $20 / 60$ & $10 / 60$ & $43 / 60$ & $17 / 60$ \\
\hline
\end{tabular}

${ }^{\times}$Midazolam group

${ }^{x \times}$ Normal saline group 


\section{ORIGINAL ARTICLE}

TABLE 2: Showing pre-sedation vital parameters

\begin{tabular}{|l|l|l|}
\hline Vital parameters & $\begin{array}{l}\text { Group M } \\
\text { (Mean } \pm \text { S.D) }\end{array}$ & $\begin{array}{l}\text { Group N } \\
\text { (Mean } \pm \text { S.D) }\end{array}$ \\
\hline $\begin{array}{l}\text { Pulse rate } \\
\text { (per minute) } \\
\begin{array}{l}\text { Respiratory rate } \\
\text { (per minute) }\end{array}\end{array}$ & $108.2 \pm 12.24$ & $114.6 \pm 13.04$ \\
$\begin{array}{l}\text { Systolic blood pressure } \\
\text { (mmHg) }\end{array}$ & $96.6 \pm 5.66$ & $96.2 \pm 6.20$ \\
$\begin{array}{l}\text { Diastolic blood pressure } \\
\text { (mmHg) }\end{array}$ & $60.33 \pm 4.10$ & $58.8 \pm 3.38$ \\
$\begin{array}{l}\text { Arterial oxygen saturation } \\
\text { (\%) }\end{array}$ & $98.96 \pm 1.06$ & $98.56 \pm 0.81$ \\
\hline
\end{tabular}

TABLE 3: Showing sedation scale

\begin{tabular}{|c|c|c|c|c|c|c|c|c|c|c|}
\hline \multirow{3}{*}{ Sedation score } & \multicolumn{10}{|c|}{ Sedation scale at different intervals (No. of patients) } \\
\hline & \multicolumn{2}{|c|}{$0 \min$} & \multicolumn{2}{|c|}{$5 \mathrm{~min}$} & \multicolumn{2}{|c|}{$10 \min ^{x}$} & \multicolumn{2}{|c|}{$15 \min ^{x}$} & \multicolumn{2}{|c|}{$20 \min ^{x}$} \\
\hline & M & $\mathrm{N}$ & M & $\mathrm{N}$ & $\mathrm{M}$ & $\mathrm{N}$ & $\mathrm{M}$ & $\mathrm{N}$ & $\mathrm{M}$ & $\mathrm{N}$ \\
\hline 1 (Agitated) & 09 & 10 & 11 & 16 & 06 & 18 & 01 & 14 & 00 & 09 \\
\hline 2 (Alert) & 21 & 20 & 19 & 14 & 19 & 12 & 12 & 16 & 07 & 18 \\
\hline 3 (Calm) & 00 & 00 & 00 & 00 & 05 & 00 & 17 & 00 & 19 & 03 \\
\hline 4 (Drowsy) & 00 & 00 & 00 & 00 & 00 & 00 & 00 & 00 & 04 & 00 \\
\hline 5 (Asleep) & 00 & 00 & 00 & 00 & 00 & 00 & 00 & 00 & 00 & 00 \\
\hline
\end{tabular}

${ }^{\times}$Statistically significant difference 


\section{ORIGINAL ARTICLE}

TABLE 4: Showing post sedation vital parameters

\begin{tabular}{|c|c|c|c|c|c|c|c|c|c|c|}
\hline \multirow{3}{*}{$\begin{array}{l}\text { Time } \\
\text { interval }\end{array}$} & \multicolumn{10}{|c|}{$\begin{array}{l}\text { Post sedation vital parameters } \\
\text { Mean }( \pm \text { S.D.) }\end{array}$} \\
\hline & \multicolumn{2}{|c|}{$\mathrm{PR}(/ \mathrm{min})$} & \multicolumn{2}{|c|}{$\mathrm{RR}(/ \mathrm{min})$} & \multicolumn{2}{|c|}{ SBP(mmHg) } & \multicolumn{2}{|c|}{$\mathrm{DBP}(\mathrm{mmHg})$} & \multicolumn{2}{|c|}{$\mathrm{Spo}_{2}(\%)$} \\
\hline & M & $\mathrm{N}$ & M & $\mathrm{N}$ & $\mathrm{M}$ & $\mathrm{N}$ & M & $\mathrm{N}$ & $\mathrm{M}$ & $\mathrm{N}$ \\
\hline $0 \mathrm{~min}$ & $\begin{array}{l}108 . \\
86 \\
( \pm 12 . \\
56)\end{array}$ & $\begin{array}{l}114 . \\
67 \\
( \pm 13 . \\
08)\end{array}$ & $\begin{array}{l}23.6 \\
6 \\
( \pm 2.4 \\
6)\end{array}$ & $\begin{array}{l}23.4 \\
6 \\
( \pm 2.6 \\
2)\end{array}$ & $\begin{array}{l}96.66 \\
( \pm 5.9 \\
9)\end{array}$ & $\begin{array}{l}96.2 \\
( \pm 6.2 \\
0)\end{array}$ & $\begin{array}{l}60.3 \\
3 \\
( \pm 4.1 \\
0)\end{array}$ & $\begin{array}{l}58.80 \\
( \pm 3.38 \\
)\end{array}$ & $\begin{array}{l}98.9 \\
6 \\
( \pm 1.0 \\
6)\end{array}$ & $\begin{array}{l}98.56 \\
( \pm 0.8 \\
1)\end{array}$ \\
\hline $5 \mathrm{~min}$ & $\begin{array}{l}109 . \\
2 \\
( \pm 13 . \\
09)\end{array}$ & $\begin{array}{l}114 . \\
13 \\
( \pm 14 . \\
89)\end{array}$ & $\begin{array}{l}24.1 \\
3 \\
( \pm 2.7 \\
2)\end{array}$ & $\begin{array}{l}24.0 \\
0 \\
( \pm 1.8 \\
2)\end{array}$ & $\begin{array}{l}97.6 \\
( \pm 5.1 \\
3)\end{array}$ & $\begin{array}{l}97.46 \\
( \pm 5.5 \\
0)\end{array}$ & $\begin{array}{l}59.9 \\
6 \\
( \pm 4.4 \\
9)\end{array}$ & $\begin{array}{l}60.13 \\
( \pm 3.23 \\
)\end{array}$ & $\begin{array}{l}99.4 \\
3 \\
( \pm 0.8 \\
1)\end{array}$ & $\begin{array}{l}98.83 \\
( \pm 0.9 \\
8)\end{array}$ \\
\hline $\begin{array}{l}10 \\
\min \square\end{array}$ & $\begin{array}{l}108 . \\
13 \\
( \pm 14 . \\
63)\end{array}$ & $\begin{array}{l}112 . \\
33 \\
( \pm 13 \\
.29)\end{array}$ & $\begin{array}{l}23.2 \\
6 \\
( \pm 2 . \\
75)\end{array}$ & $\begin{array}{l}25.1 \\
3 \\
( \pm 2 . \\
14)\end{array}$ & $\begin{array}{l}96.03 \\
( \pm 5.6 \\
8)\end{array}$ & $\begin{array}{l}98.13 \\
( \pm 5.4 \\
3)\end{array}$ & $\begin{array}{l}59.7 \\
3 \\
( \pm 5 . \\
11)\end{array}$ & $\begin{array}{l}62.13 \\
( \pm 3.27 \\
)\end{array}$ & $\begin{array}{l}99.3 \\
6 \\
( \pm 0 . \\
85)\end{array}$ & $\begin{array}{l}99.20 \\
( \pm 0.9 \\
2)\end{array}$ \\
\hline $\begin{array}{l}15 \\
\min \square\end{array}$ & $\begin{array}{l}105 \\
4 \\
( \pm 12 \\
.10)\end{array}$ & $\begin{array}{l}111 . \\
93 \\
( \pm 12 \\
.65)\end{array}$ & $\begin{array}{l}22.6 \\
( \pm 2 . \\
23)\end{array}$ & $\begin{array}{l}25.6 \\
( \pm 1 . \\
85)\end{array}$ & $\begin{array}{l}95.4 \\
( \pm 5.7 \\
3)\end{array}$ & $\begin{array}{l}98.8 \\
( \pm 5.6 \\
4)\end{array}$ & $\begin{array}{l}58.1 \\
3 \\
( \pm 5 . \\
70)\end{array}$ & $\begin{array}{l}62.00 \\
( \pm 3.19 \\
)\end{array}$ & $\begin{array}{l}98.8 \\
6 \\
( \pm 1 . \\
04)\end{array}$ & $\begin{array}{l}99.36 \\
( \pm 0.8 \\
5)\end{array}$ \\
\hline $\begin{array}{l}20 \\
\min \square\end{array}$ & $\begin{array}{l}103 . \\
93 \\
( \pm 11 \\
.22)\end{array}$ & $\begin{array}{l}111 . \\
80 \\
( \pm 13 \\
.73)\end{array}$ & $\begin{array}{l}22.4 \\
6 \\
( \pm 2 . \\
27)\end{array}$ & $\begin{array}{l}25.8 \\
( \pm 2 . \\
18)\end{array}$ & $\begin{array}{l}95.26 \\
( \pm 5.9 \\
5)\end{array}$ & $\begin{array}{l}99.53 \\
( \pm 5.0 \\
0)\end{array}$ & $\begin{array}{l}58.6 \\
6 \\
( \pm 4 . \\
07)\end{array}$ & $\begin{array}{l}63.20 \\
( \pm 2.99 \\
)\end{array}$ & $\begin{array}{l}98.7 \\
3 \\
( \pm 0 . \\
98)\end{array}$ & $\begin{array}{l}99.16 \\
( \pm 0.5 \\
9)\end{array}$ \\
\hline
\end{tabular}

Statistically significant difference

TABLE 5: Showing separation score

\begin{tabular}{|c|l|l|l|}
\hline \multirow{2}{*}{ Score } & \multicolumn{2}{|l|}{ Number of children } \\
\cline { 2 - 4 } & Group M & Group N & Total \\
\hline 1 (Excellent) & $09 / 30$ & $01 / 30$ & $10 / 60$ \\
\hline 2 (Good) & $13 / 30$ & $07 / 30$ & $20 / 60$ \\
\hline 3 (Fair) & $07 / 30$ & $14 / 30$ & $21 / 60$ \\
\hline 4 (Poor) & $01 / 30$ & $08 / 30$ & $09 / 60$ \\
\hline Total & 30 & 30 & 60 \\
\hline
\end{tabular}




\section{ORIGINAL ARTICLE}

TABLE 6: Showing acceptance to mask

\begin{tabular}{|c|l|l|l|}
\hline \multirow{2}{*}{ Score } & \multicolumn{3}{|l|}{ Number of children } \\
\cline { 2 - 4 } & Group M No. (\%) & Group N No. (\%) & Total No. (\%) \\
\hline 1 (Excellent) & $08(26.66)$ & $01(3.33)$ & $09(15.00)$ \\
\hline 2 (Good) & $18(60.00)$ & $06(20.00)$ & $24(40.00)$ \\
\hline 3 (Poor) & $04(13.33)$ & $23(76.66)$ & $27(45.00)$ \\
\hline Total & 30 & 30 & 60 \\
\hline
\end{tabular}

TABLE 7: Showing Intraoperative vital parameters

\begin{tabular}{|c|c|c|c|c|c|c|c|c|}
\hline \multirow{3}{*}{$\begin{array}{l}\text { Time } \\
\text { interval }\end{array}$} & \multicolumn{8}{|c|}{$\begin{array}{l}\text { Intraoperative vital parameters } \\
\text { Mean }( \pm \text { S.D.) }\end{array}$} \\
\hline & \multicolumn{2}{|c|}{$\mathrm{PR}(/ \mathrm{min})$} & \multicolumn{2}{|c|}{ SBP (mmHg) } & \multicolumn{2}{|c|}{ DBP (mmHg) } & \multicolumn{2}{|c|}{ SPO2 (\%) } \\
\hline & $\mathrm{A}$ & $\mathrm{B}$ & $\mathrm{A}$ & $\mathrm{B}$ & $\mathrm{A}$ & $\mathrm{B}$ & $\mathrm{A}$ & B \\
\hline $5 \mathrm{~min}$ & $\begin{array}{l}105.00 \\
( \pm 11.37)\end{array}$ & $\begin{array}{l}108.53 \\
( \pm 15.27)\end{array}$ & $\begin{array}{l}95.8 \\
( \pm 6.13)\end{array}$ & $\begin{array}{l}94.6 \\
( \pm 6.58)\end{array}$ & $\begin{array}{l}59.6 \\
( \pm 3.61)\end{array}$ & $\begin{array}{l}58.4 \\
( \pm 4.43)\end{array}$ & $\begin{array}{l}99.23 \\
( \pm 0.97)\end{array}$ & $\begin{array}{l}99.2 \\
( \pm 1.03)\end{array}$ \\
\hline $10 \mathrm{~min}$ & $\begin{array}{l}108.00 \\
( \pm 11.93)\end{array}$ & $\begin{array}{l}113.26 \\
( \pm 15.99)\end{array}$ & $\begin{array}{l}96.66 \\
( \pm 5.39)\end{array}$ & $\begin{array}{l}95.6 \\
( \pm 6.79)\end{array}$ & $\begin{array}{l}60.33 \\
( \pm 4.00)\end{array}$ & $\begin{array}{l}58.93 \\
( \pm 5.32)\end{array}$ & $\begin{array}{l}99.16 \\
( \pm 1.01)\end{array}$ & $\begin{array}{l}99.26 \\
( \pm 0.98)\end{array}$ \\
\hline $15 \mathrm{~min}$ & $\begin{array}{l}108.86 \\
( \pm 12.43)\end{array}$ & $\begin{array}{l}113.33 \\
( \pm 14.90)\end{array}$ & $\begin{array}{l}95.6 \\
( \pm 6.11)\end{array}$ & $\begin{array}{l}96.0 \\
( \pm 5.58)\end{array}$ & $\begin{array}{l}58.73 \\
( \pm 5.36)\end{array}$ & $\begin{array}{l}58.33 \\
( \pm 4.66)\end{array}$ & $\begin{array}{l}99.23 \\
( \pm 0.97)\end{array}$ & $\begin{array}{l}99.33 \\
( \pm 1.09)\end{array}$ \\
\hline $30 \mathrm{~min}$ & $\begin{array}{l}106.33 \\
( \pm 13.44)\end{array}$ & $\begin{array}{l}111.24 \\
( \pm 15.29)\end{array}$ & $\begin{array}{l}95.36 \\
( \pm 5.62)\end{array}$ & $\begin{array}{l}95.17 \\
( \pm 5.54)\end{array}$ & $\begin{array}{l}58.53 \\
( \pm 3.96)\end{array}$ & $\begin{array}{l}57.93 \\
( \pm 4.08)\end{array}$ & $\begin{array}{l}99.2 \\
( \pm 0.84)\end{array}$ & $\begin{array}{l}99.27 \\
( \pm 0.95)\end{array}$ \\
\hline $45 \mathrm{~min}$ & $\begin{array}{l}107.41 \\
( \pm 13.10)\end{array}$ & $\begin{array}{l}112.83 \\
( \pm 15.81)\end{array}$ & $\begin{array}{l}95.41 \\
( \pm 5.02)\end{array}$ & $\begin{array}{l}95.90 \\
( \pm 5.80)\end{array}$ & $\begin{array}{l}58.58 \\
( \pm 4.66)\end{array}$ & $\begin{array}{l}58.36 \\
( \pm 2.66)\end{array}$ & $\begin{array}{l}99.2 \\
( \pm 0.93)\end{array}$ & $\begin{array}{l}99.27 \\
( \pm 0.88)\end{array}$ \\
\hline $60 \mathrm{~min}$ & $\begin{array}{l}105.44 \\
( \pm 10.86)\end{array}$ & $\begin{array}{l}111.28 \\
( \pm 15.97)\end{array}$ & $\begin{array}{l}95.27 \\
( \pm 5.89)\end{array}$ & $\begin{array}{l}96.14 \\
( \pm 4.25)\end{array}$ & $\begin{array}{l}58.77 \\
( \pm 4.00)\end{array}$ & $\begin{array}{l}58.0 \\
( \pm 2.35)\end{array}$ & $\begin{array}{l}99.11 \\
( \pm 0.90)\end{array}$ & $\begin{array}{l}99.21 \\
( \pm 0.89)\end{array}$ \\
\hline $75 \mathrm{~min}$ & $\begin{array}{l}108.50 \\
( \pm 6.60)\end{array}$ & $\begin{array}{l}108.00 \\
( \pm 18.33)\end{array}$ & $\begin{array}{l}93.0 \\
( \pm 6.21)\end{array}$ & $\begin{array}{l}94.66 \\
( \pm 2.30)\end{array}$ & $\begin{array}{l}60.0 \\
( \pm 1.63)\end{array}$ & $\begin{array}{l}58.0 \\
( \pm 3.46)\end{array}$ & $\begin{array}{l}99.0 \\
( \pm 0.81)\end{array}$ & $\begin{array}{l}99.0 \\
( \pm 0.81)\end{array}$ \\
\hline
\end{tabular}

TABLE 8: Showing Recovery score

\begin{tabular}{|l|l|l|}
\hline \multirow{2}{*}{ Time interval } & \multicolumn{2}{|l|}{ Recovery score } \\
\cline { 2 - 3 } & $\begin{array}{l}\text { Group M } \\
\text { Mean } \pm \text { S.D. }\end{array}$ & $\begin{array}{l}\text { Group N } \\
\text { Mean } \pm \text { S.D. }\end{array}$ \\
\hline $10 \mathrm{~min}$ & $8.5 \pm 1.07$ & $8.76 \pm 0.97$ \\
\hline $20 \mathrm{~min}$ & $9.23 \pm 0.81$ & $9.56 \pm 0.62$ \\
\hline $30 \mathrm{~min}$ & $10 \pm 0$ & $10 \pm 0$ \\
\hline
\end{tabular}




\section{ORIGINAL ARTICLE}

FIGURE 1: Comparison between Group M and Group N

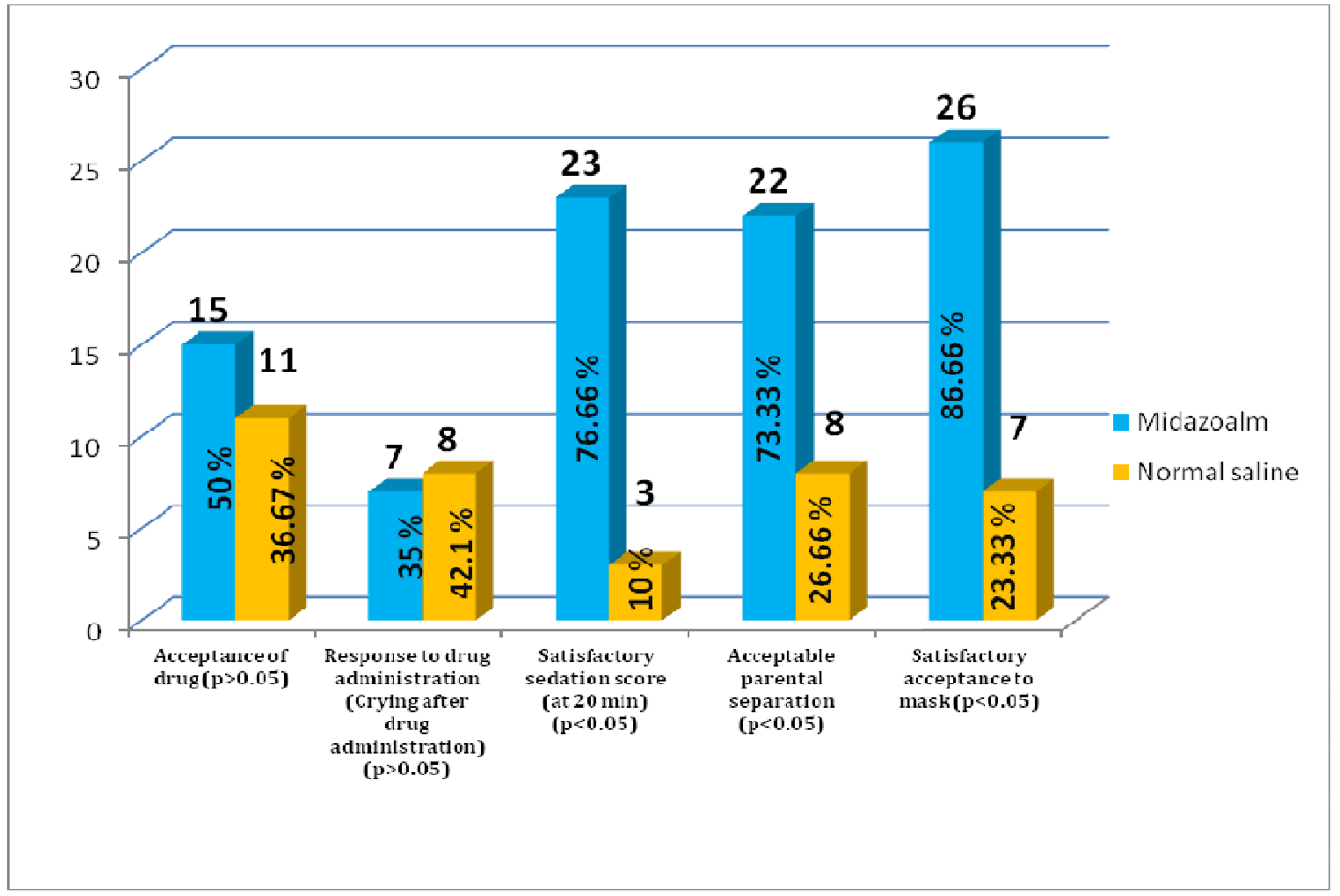

FIGURE 2

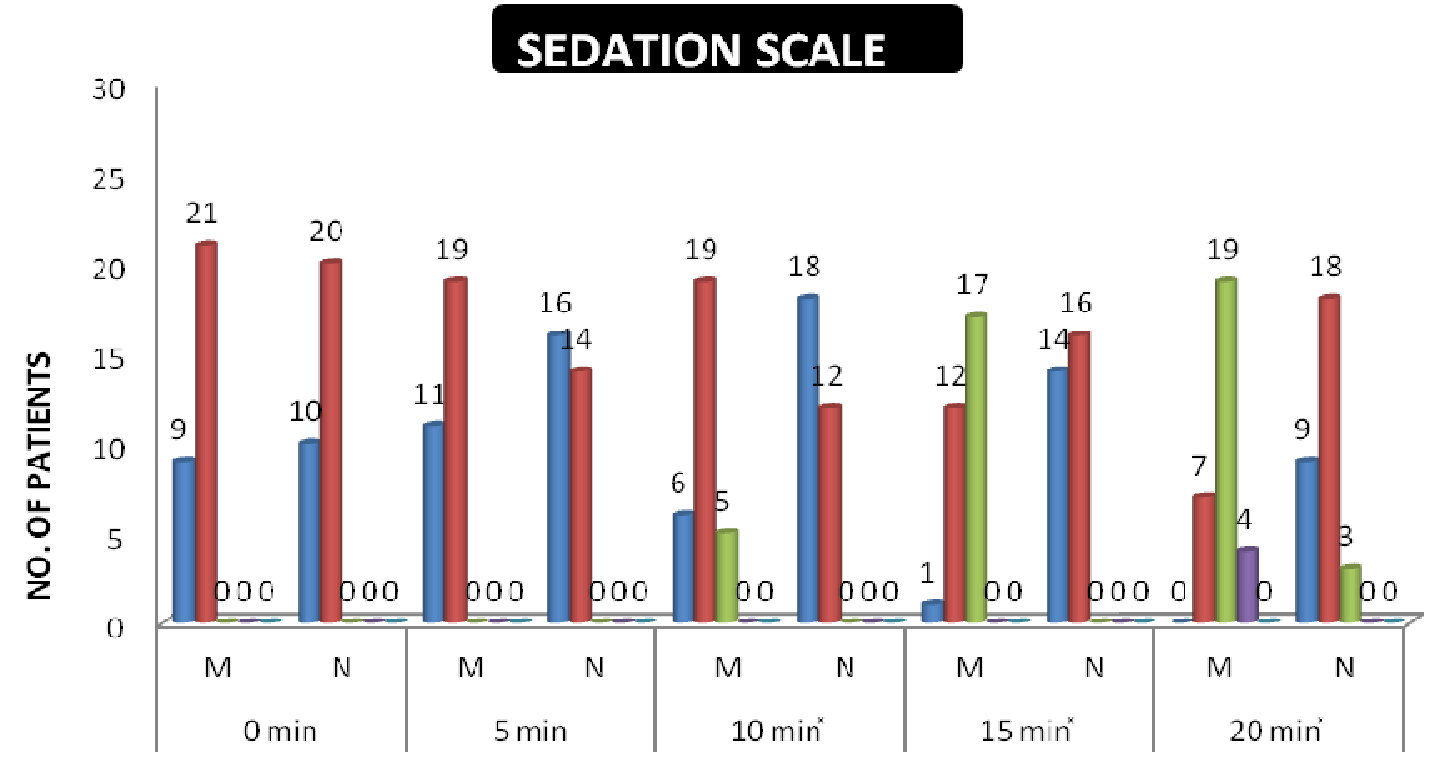

SEDATION SCORE AT DIFFERENT TIME INTERVAL

-1 (Agitated) $\square 2$ (Alert) $\square 3$ (Calm) $\square 4$ (Drowsy) $\square$ (Asleep) 